\title{
Assessing Karenia brevis red tide as a mortality factor of sea turtles in Florida, USA
}

\author{
Allen M. Foley ${ }^{1, *}$, Brian A. Stacy ${ }^{2}$, Paul Schueller ${ }^{3}$, Leanne J. Flewelling ${ }^{4}$, \\ Barbara Schroeder ${ }^{5}$, Karrie Minch ${ }^{6}$, Deborah A. Fauquier ${ }^{7,8}$, Jerris J. Foote ${ }^{7,9}$, \\ Charles A. Manire ${ }^{7,10}$, Karen E. Atwood ${ }^{4,11}$, April A. Granholm ${ }^{4}$, Jan H. Landsberg ${ }^{4}$ \\ ${ }^{1}$ Florida Fish and Wildlife Conservation Commission, Fish and Wildlife Research Institute, Jacksonville Field Laboratory, \\ Jacksonville, Florida 32218, USA \\ ${ }^{2}$ NOAA, National Marine Fisheries Service, Office of Protected Resources, University of Florida (duty station), Gainesville, \\ Florida 32611, USA \\ ${ }^{3}$ Florida Fish and Wildlife Conservation Commission, Fish and Wildlife Research Institute, \\ Center for Biostatistics and Modeling, Gainesville, Florida 32653, USA \\ ${ }^{4}$ Florida Fish and Wildlife Conservation Commission, Fish and Wildlife Research Institute, St. Petersburg, Florida 33701, USA \\ ${ }^{5}$ NOAA, National Marine Fisheries Service, Office of Protected Resources, Silver Spring, Maryland 20910, USA \\ ${ }^{6}$ Florida Fish and Wildlife Conservation Commission, Fish and Wildlife Research Institute, c/o Marine Discovery Center, \\ New Smyrna Beach, Florida 32169, USA \\ ${ }^{7}$ Mote Marine Laboratory, Sarasota, Florida 34236, USA

\footnotetext{
${ }^{8}$ Present address: National Marine Fisheries Service, Office of Protected Resources, Silver Spring, Maryland 20910, USA

${ }^{9}$ Present address: Operational Management, Sarasota County Government, Parks, Recreation and Natural Resources, Natural Area Parks and Preserves, Sarasota, Florida 34231, USA
} \\ ${ }^{10}$ Present address: Loggerhead Marinelife Center, Juno Beach, Florida 33408, USA \\ ${ }^{11}$ Present address: University of South Florida, Sarasota-Manatee, Sarasota, Florida 34243, USA
}

\begin{abstract}
Data on Karenia brevis red tides $\left(\geq 10^{5}\right.$ cells $\left.\mathrm{l}^{-1}\right)$ and on dead or debilitated (i.e. stranded) Kemp's ridleys Lepidochelys kempii, loggerheads Caretta caretta, green turtles Chelonia mydas, hawksbills Eretmochelys imbricata, and leatherbacks Dermochelys coriacea documented in Florida during 1986-2013 were evaluated to assess red tides as a sea turtle mortality factor. Unusually large numbers of stranded sea turtles were found coincident with red tides primarily along Florida's Gulf coast but also along a portion of Florida's Atlantic coast. These strandings were mainly adult and large immature loggerheads and Kemp's ridleys, and small immature green turtles and hawksbills. Unusually large numbers of stranded leatherbacks never coincided with red tide. For the 3 most common species, results of stranding data modeling, and of investigations that included determining brevetoxin concentrations in samples collected from stranded turtles, all indicated that red tides were associated with greater and more frequent increases in the numbers of stranded loggerheads and Kemp's ridleys than in the number of stranded green turtles. The mean annual number of stranded sea turtles attributed to $K$. brevis red tide was 80 (SE = 21.6 , range $=2-338$ ). Considering typical stranding probabilities, the overall mortality was probably 5-10 times greater. Red tide accounted for a substantial portion of all stranded loggerheads $(7.1 \%)$ and Kemp's ridleys $(17.7 \%)$, and a smaller portion of all stranded green turtles $(1.6 \%)$. Even though $K$. brevis red tides occur naturally, the mortality they cause needs to be considered when managing these threatened and endangered species.
\end{abstract}

KEY WORDS: Sea turtles $\cdot$ Karenia brevis $\cdot$ Mortality $\cdot$ Brevetoxin $\cdot$ Red tide $\cdot$ Florida

${ }^{*}$ Corresponding author: allen.foley@myfwc.com
(C) The authors 2019. Open Access under Creative Commons by Attribution Licence. Use, distribution and reproduction are unrestricted. Authors and original publication must be credited. 


\section{INTRODUCTION}

The term 'red tide' generally describes a harmful algal bloom (HAB). In the Gulf of Mexico, it refers specifically to a bloom of the toxic dinoflagellate Karenia brevis, which can appear as a reddish discoloration of the water (Tester \& Steidinger 1997). $K$. brevis regularly occurs in background concentra-

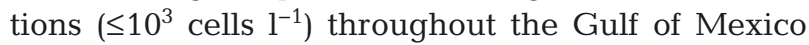
and the South Atlantic Bight (Tester \& Steidinger 1997). Blooms are characterized by any cell concentrations above that background level (Steidinger 2009).

The initiation of a $K$. brevis bloom is a complex process that begins in oligotrophic waters of the Gulf of Mexico from 18 to $74 \mathrm{~km}$ offshore (Tester \& Steidinger 1997, Walsh \& Steidinger 2001, Walsh et al. 2006, Vargo et al. 2008, Weisberg et al. 2016). Blooms of $K$. brevis usually develop along Florida's Gulf coast (Tester \& Steidinger 1997), but the Florida Current and Gulf Stream can transport these blooms to Florida's Atlantic coast and occasionally into the rest of the South Atlantic Bight (Murphy et al. 1975, Tester et al. 1991). These red tides are natural phenomena that have occurred in the Gulf of Mexico for at least several hundred years (Tester \& Steidinger 1997, Steidinger 2009). If a red tide is transported to a nearshore area, nutrient inputs from coastal pollution might help maintain and intensify it, but pollution does not appear to influence the initiation of these blooms (Steidinger \& Ingle 1972, Weisberg et al. 2016).

K. brevis produces potent neurotoxins known as brevetoxins (Baden 1989, Landsberg 2002). Marine animal mortalities associated with $K$. brevis red tides have been well documented since 1844 (reviewed by Landsberg 2002), but the causative dinoflagellate was not identified until more than a century later (Davis 1948). It was another 20 yr before the brevetoxins were first characterized (McFarren et al. 1965). Fish are most commonly killed during these red tides (reviewed by Landsberg 2002), but substantial mortality has often been documented in higher vertebrates such as sea turtles (cheloniids; Fauquier et al. 2013a), birds (waterfowl, seabirds, and shorebirds; Forrester et al. 1977, Kreuder et al. 2002, van Deventer et al. 2012, Fauquier et al. 2013b), and marine mammals (bottlenose dolphins Tursiops truncatus and Florida manatees Trichechus manatus latirostris; O'Shea et al. 1991, Bossart et al. 1998, Flewelling et al. 2005, Twiner et al. 2012). Mortality of higher vertebrates due to red tide is anticipated when concen-

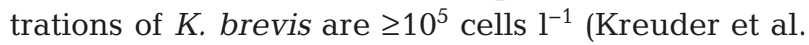

2002, Landsberg et al. 2009, Twiner et al. 2011, Fauquier et al. 2013a,b).

Higher vertebrates can inhale aerosolized brevetoxin, but ingesting food containing brevetoxin appears to be the most significant means of exposure (Landsberg et al. 2009). Clinical signs of brevetoxicosis among higher vertebrates include lethargy, weakness, lack of coordination (i.e. the inability to stay upright, or swimming in circles), and unusual muscular activity (e.g. generalized twitching, spasms, head bobbing, seizures) (Quick \& Henderson 1975, Bossart et al. 1998, Castle et al. 2013, Fauquier et al. 2013a,b). Necropsies of these animals typically reveal no specific gross or pathologic abnormalities related to brevetoxicosis (Kreuder et al. 2002, Twiner et al. 2012, Fauquier et al. 2013a).

The role of $K$. brevis red tides in marine animal mortalities is not always straightforward. For example, in some mortality events involving Florida manatees and bottlenose dolphins, carcasses had relatively high concentrations of brevetoxin in collected samples even though the mortalities did not coincide with a red tide. In such cases, brevetoxin vectors (e.g. fish) or brevetoxin reservoirs (e.g. seagrass) resulted in either remote or delayed exposure (Flewelling et al. 2005). Thus, identifying a red tide as the cause of a mortality event may depend entirely on being able to determine the significance of any brevetoxin found in carcasses.

The effects of brevetoxin are dose-dependent, and not every exposure is lethal (Cocilova \& Milton 2016). Higher marine vertebrates living in areas where $K$. brevis occurs can test positive for brevetoxin when not associated with a large-scale mortality event (Fire et al. 2007, Atwood 2008), when not suspected to have died from brevetoxicosis (Flewelling 2008, Capper et al. 2013), or when alive and found to be behaving normally (Twiner et al. 2011, Perrault et al. 2014, 2016). The brevetoxin concentrations documented under these circumstances are the best available representatives of baseline (i.e. probable subclinical) exposure, and higher concentrations documented during large-scale mortality events coincident with red tides probably indicate the amounts of brevetoxin necessary to cause acute mortality (Fire et al. 2007, Landsberg et al. 2009, Twiner et al. 2011).

Research on the mortality of higher vertebrates associated with $K$. brevis red tides has typically focused on 1 or 2 individual mortality events over relatively short periods (2 mo to $2 \mathrm{yr}$ Forrester et al. 1977, Geraci 1989, O'Shea et al. 1991, Bossart et al. 1998, Flewelling et al. 2005, van Deventer et al. 2012, Fauquier et al. 2013a,b). In one longer-term study, 
Twiner et al. (2012) examined mortality of bottlenose dolphins related to red tides over an 8 yr period along a $300 \mathrm{~km}$ stretch of the northern Gulf coast of Florida. We are not aware of any similar, long-term assessments of sea turtle mortality associated with red tides. For threatened and endangered species such as sea turtles, thoroughly characterizing threats like red tides and regularly quantifying the mortality they cause is essential for successful recovery planning (Clark et al. 2002, Lawler et al. 2002).

The Florida Fish and Wildlife Conservation Commission coordinates many long-term state-wide monitoring programs. Among these are the Florida Sea Turtle Stranding and Salvage Network (FLSTSSN) and HAB monitoring. Dead, sick, and injured sea turtles (i.e. stranded sea turtles) have been documented in some areas of Florida since 1980, and a consistent effort statewide began in 1986. Six species of sea turtles have been documented in Florida as strandings and include loggerheads Caretta caretta, green turtles Chelonia mydas, Kemp's ridleys Lepidochelys kempii, hawksbills Eretmochelys imbricata, leatherbacks Dermochelys coriacea, and olive ridleys L. olivacea. The HAB monitoring program has been documenting K. brevis red tides in Florida since 1954, and more regular monitoring (especially along the southern Gulf coast of Florida) began in the mid-1990s (Steidinger 2009). Our objective was to assess K. brevis red tides as a mortality factor of sea turtles by species in Florida during 1986-2013 using data from these 2 monitoring programs. We evaluated these data to determine if numbers of stranded sea turtles (as an index of sea turtle mortality) increased coincident with red tide and during which months and in what areas of Florida this occurred. We also measured brevetoxin concentrations in samples taken from strandings to determine baseline exposure and to characterize concentrations suspected of causing acute mortality. Finally, we used this information to estimate the number of stranded sea turtles and the likely overall sea turtle mortality in Florida that could be attributed to red tide.

\section{MATERIALS AND METHODS}

\subsection{Collection of data on stranded sea turtles and red tides}

For the period of 1986-2013, we used data collected on stranded sea turtles by the FLSTSSN (methodology described by Foley et al. 2005) and data on cell concentrations of Karenia brevis in seawater samples col- lected by the HAB monitoring program (methodology described by Steidinger 2009). For the purposes of the present study, we defined a red tide as a $K$. brevis bloom with a concentration of $\geq 10^{5}$ cells $\mathrm{l}^{-1}$. The discovery locations of stranded sea turtles and of red tides were grouped by zone (Fig. 1), and the dates on which they were documented were grouped by month.

\subsection{Data analysis}

To determine if numbers of stranded sea turtles in Florida were significantly elevated during red tides while accounting for other factors that could influence stranding numbers, we first constructed Poisson regressions relating numbers of strandings (per month per zone) to various predictor variables (including red tide) over a 28 yr period (1986-2013). This was done for each of the 3 most common species (loggerheads, green turtles, and Kemp's ridleys). The less common species (hawksbills, leatherbacks, and olive ridleys) were not modeled because they accounted for relatively few strandings (mean of $<25 \mathrm{yr}^{-1}$ by species), especially those coincident with red tide (mean of $<2 \mathrm{yr}^{-1}$ by species).

The predictor variables included in the regressions were month, zone, lag count (LCT: the number of stranded turtles found in the same zone during the previous month), ongoing red tide (ORT: whether red tide was found in the same zone and during the same month as stranded turtles), and lag red tide (LRT: whether red tide was found in the same zone as stranded turtles but during the previous month and not during the same month). Month and zone were included because numbers of stranded turtles varied consistently by both, with the highest numbers of strandings occurring during the spring and the lowest occurring during the fall, and with some zones always having more strandings than other zones. LCT was included because high (or low) stranding numbers in a zone for a given month could be related to high (or low) stranding numbers in the same zone during the previous month. ORT was included to account for the effect of an ongoing red tide on stranding numbers. LRT was included to account for any effects of red tide on the numbers of stranded turtles that may have continued for 1 mo after the red tide dissipated (delayed mortality).

The 2 simplest Poisson regression models included effects of month, zone, ORT, and LRT, with and without an interaction between month and ORT. The simple models were then enhanced to include LCT with different combinations of interactions between 


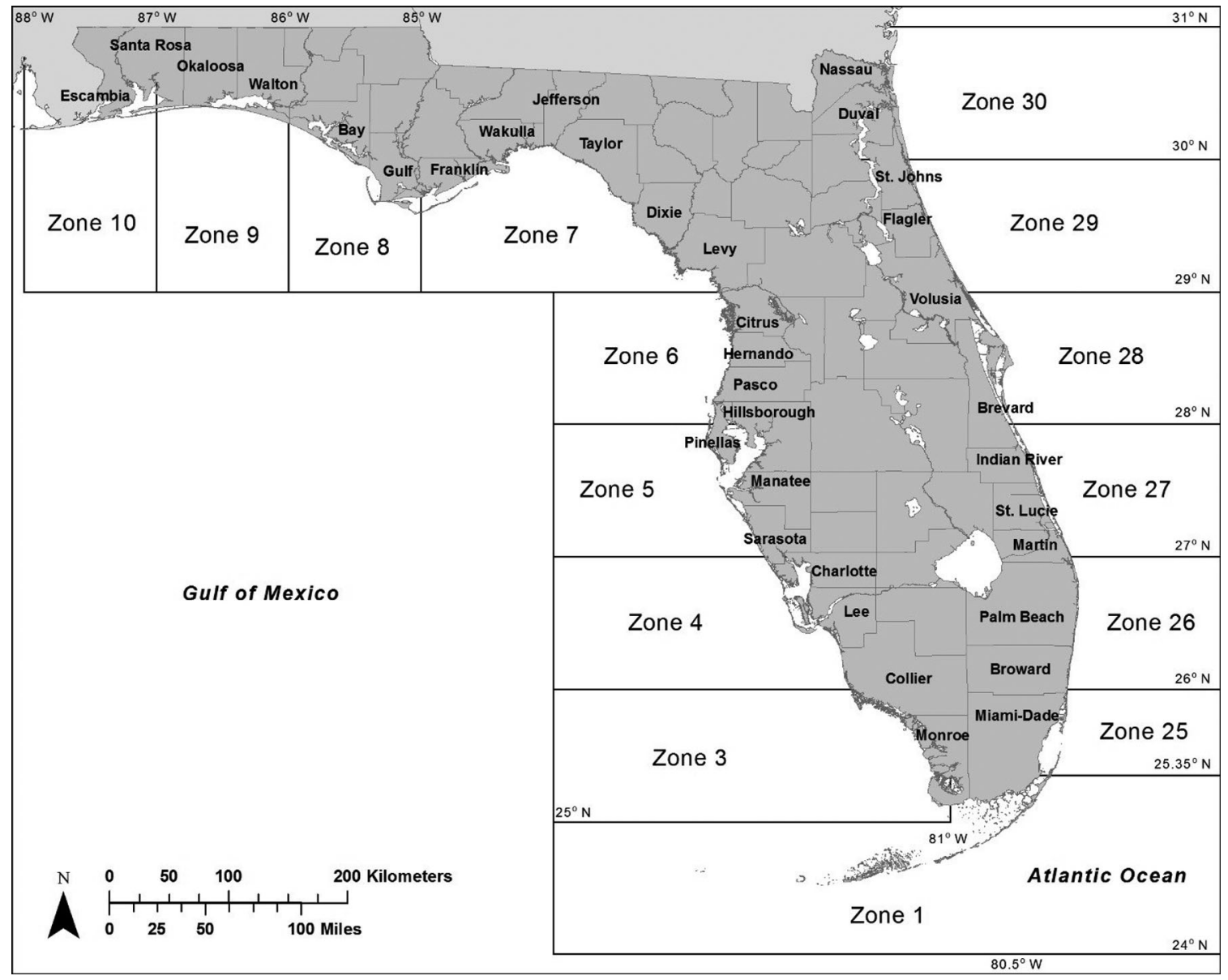

Fig. 1. Modified National Marine Fisheries Service Statistical Zones and coastal counties in Florida. For this study, the original Zones 1, 2, and 24, and the southern portion of Zone 25 were combined to create a modified Zone 1 . The original Zone 25 was reduced (southern boundary at $25.35^{\circ} \mathrm{N}$ instead of $25.00^{\circ} \mathrm{N}$ ). In Zones 10 and 30, only stranded sea turtles found in Florida are reported here

month, ORT, and LRT. All regression models were fit in R (R Development Core Team 2008), and Akaike's information criterion (AIC; Akaike 1973) was used to determine the most plausible model. The Poisson regression outputs are displayed in Table 1.

The Poisson regressions exhibited overdispersion and temporally autocorrelated residuals. To account for this, we constructed a Bayesian overdispersed Poisson regression for each species. We included all predictor variables and interactions in the Bayesian models because the corresponding Poisson regression carried substantial AIC weight (see Table 1). However, in the Bayesian model, the effect of zone was treated as a random effect. The Bayesian models also included an occasion-specific random effect (unique for the month and year within each zone) that was multivariate-normally distributed with means of 0 and an autoregressive covariance matrix estimated from the data. Consequently, a random effect term for each count could be estimated that accounted for both overdispersion and temporal autocorrelation (Kéry \& Schaub 2010). This model was expressed as follows:

$$
\begin{gathered}
y_{z, y, m} \sim \operatorname{Poi}\left(\lambda_{i}\right) \\
\log \left(\lambda_{i}\right)=X \beta_{j}+\varepsilon_{\text {zone }}+\varepsilon_{o c c} \\
\varepsilon_{\text {zone }} \sim \operatorname{Norm}\left(0, \sigma_{\text {zone }}\right) \\
\varepsilon_{\text {occ }} \sim \operatorname{MVNorm}\left(0, \Sigma_{\text {occ }(A R)}\right) \\
\sum_{o c c(A R)}=\sigma_{z, o c c}^{2} \times\left[\begin{array}{ccccc}
1 & \rho & \rho^{2} & \ldots & \rho^{n-1} \\
\rho & 1 & \rho & \ldots & \rho^{n-2} \\
\rho^{2} & \rho & 1 & \ldots & \rho^{n-3} \\
\vdots & \vdots & \vdots & \ddots & \vdots \\
\rho^{n-1} & \rho^{n-2} & \rho^{n-3} & \ldots & 1
\end{array}\right]
\end{gathered}
$$

where $y_{z, y, m}$ is the number of strandings in a given zone, year, and month; $\lambda_{i}$ is the mean number of expected strandings for a particular count; $X$ is a 


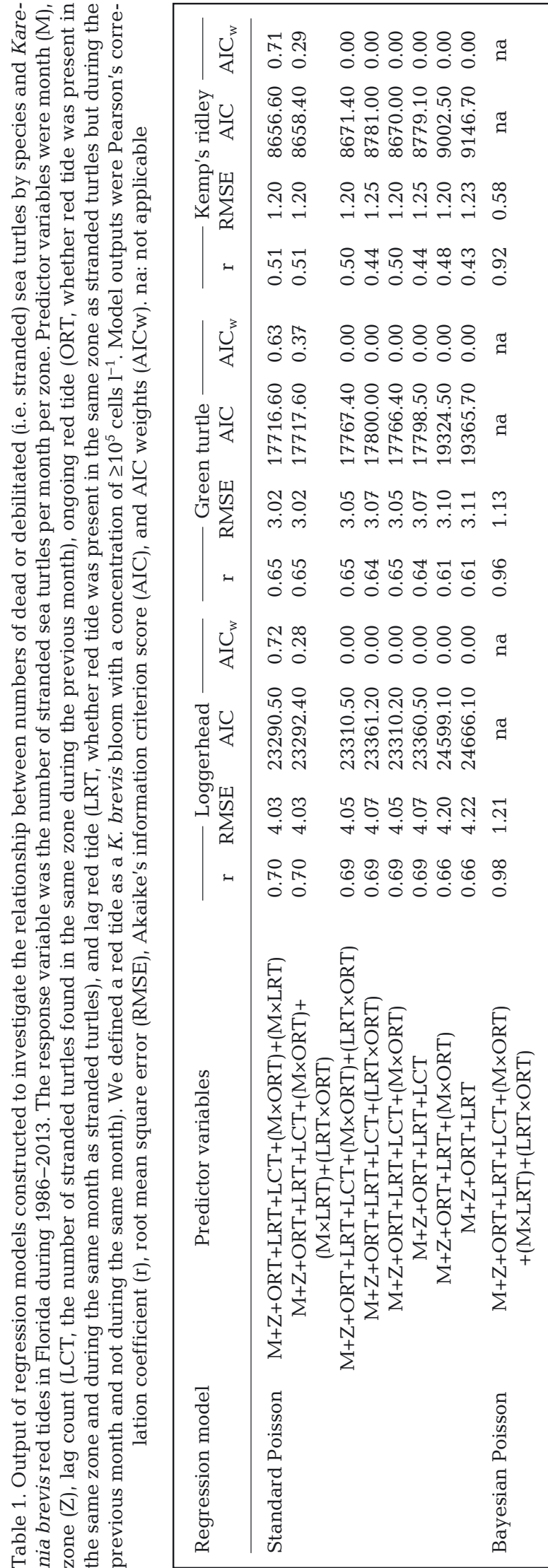

design matrix $\beta_{j}$ is a vector of unknown regression parameters; $\varepsilon_{z o n e}$ is the random effect of zone; $\varepsilon_{\text {occ }}$ is the occasion-specific temporal random effect; and $\Sigma_{o c c(A R)}$ is the autoregressive covariance matrix of the occasion-specific temporal random effect, which included parameters for the zone-specific standard deviation of the random effect $\sigma_{z, o c c}$ and the correlation among occasions $\rho$.

The Bayesian Poisson regressions were fit using Markov Chain Monte Carlo (MCMC) in program JAGS (Plummer 2003). All parameters were given diffuse priors. For all regression parameters, a normal prior distribution with a mean of 0 and a standard deviation of 100 was used. For all standard deviations, a uniform prior distribution from 0 to 20 was used. For the correlation parameter $\rho$ of the occasionspecific random effect covariance matrix, a uniform distribution from -1 to 1 was used. For the MCMC chains, we ran an adaptive phase of 20000 iterations, after which we discarded a burn-in period of 10000 iterations, and then followed that with a sampling of 20000 iterations. Convergence of the chains to the stationary distribution was determined by using $\widehat{R}$ (Gelman \& Rubin 1992). Once values of $\widehat{R}$ were $<1.1$ for all parameters, we considered the model as converged. For all estimated parameters, $95 \%$ credible intervals were based on the 2.5 and 97.5 percentiles of the posterior distribution. The outputs of the Bayesian Poisson regressions are also shown in Table 1.

To assess their significance, we used exponentiation to convert the parameter estimates of the Bayesian Poisson regressions to multiplicative effects on numbers of stranded sea turtles (Gelman \& Hill 2007). We also determined the combined multiplicative effects of ORT and LRT (both [ORT + LRT + ORT $\times$ LRT] and [ORT + LRT]) on the numbers of stranded turtles to assess the significance of at least 2 consecutive months of red tide (CRT). The predicted effects of ORT, LRT, and CRT were modeled monthly, while the predicted effects of LCT and all other parameters were modeled annually. We considered any multiplicative effects with $95 \%$ credible intervals that did not overlap 1 as significant.

\subsection{Necropsies and brevetoxin analysis}

Necropsies were conducted on a subset of stranded sea turtles following the guidance of Wolke \& George (1981). Samples collected for brevetoxin testing included 1 or more of the following: liver, lung, kidney, contents of the upper gastrointestinal tract (esophagus, stomach, or small intestine), and contents of 
the lower gastrointestinal tract including feces. From live-stranded sea turtles, fecal samples were collected opportunistically, and blood was collected as described by Owens \& Ruiz (1980). All samples were stored frozen at $-20^{\circ} \mathrm{C}$.

Samples for brevetoxin testing were processed as described by Whitney et al. (1997) (prior to 1998) or by Fauquier et al. (2013a). Brevetoxin-3 (PbTx-3)concentrations were measured by competitive ELISA (Naar et al. 2002) with modifications described by Flewelling (2008). We report values as ng PbTx-3 eq. $\mathrm{g}^{-1}$ for all samples except for blood and plasma, for which we report values as ng PbTx-3 eq. $\mathrm{ml}^{-1}$. The lower brevetoxin concentration detection limits for Steuthe assays were $5 \mathrm{ng} \mathrm{g}^{-1}$ for tissue samples, gut

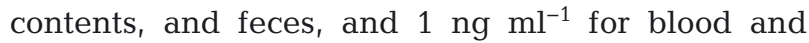
plasma. For statistical analyses, we considered a result below the detection limit as a 0 .

Samples were grouped according to the red tide status where the stranded turtle was found. These groups were (1) samples from stranded turtles found in a zone during a month without a red tide and without a red tide during the previous 3 mo (i.e. the no red tide group), (2) samples from stranded turtles found in a zone during a month without a red tide but where a red tide had occurred during at least 1 of the previous 3 mo (i.e. the recent red tide group), and (3) samples from stranded turtles found in a zone during a month with red tide (i.e. the red tide group). We chose the no red tide sample group to characterize baseline concentrations of brevetoxin (if it was represented by at least 5 samples). We separated the recent red tide sample group from the no red tide sample group (both were from stranded turtles found when there was no red tide) because brevetoxins are known to persist for up to 3 mo in diet items of sea turtles (benthic invertebrates and seagrasses; Dickey et al. 1999 and Flewelling et al. 2005, respectively). We chose the red tide sample group to identify concentrations of brevetoxin suspected of causing acute mortality.

Brevetoxin concentrations were compared to detect any differences among the samples from different groups for each species. Only groups with at least 5 samples were used in the comparisons. None of the groups had brevetoxin concentrations that were normally distributed (as determined by Shapiro-Wilk normality tests), so non-parametric analyses were used. First, a Wilcoxon rank sum test was used to compare brevetoxin concentrations in the red tide group to those in the recent red tide group. If there was no difference ( $p \geq 0.05)$, these 2 groups were combined, and then the brevetoxin concentrations in that combined group were compared to those in the no red tide group using the same test (differences considered significant at $\mathrm{p}<0.01$ ). If there was a difference in the brevetoxin concentrations between the red tide group and the recent red tide group ( $\mathrm{p}<$ 0.05), then a Kruskal-Wallis rank sum test was used to compare the concentrations among all 3 groups. If there was a significant difference in a 3-group comparison ( $p<0.05)$, Dunn's test was used to make pairwise comparisons (differences considered significant at $\mathrm{p}<0.01)$.

\subsection{Estimation of strandings and overall mortality attributable to red tide}

We identified a zone in which red tide was likely a sea turtle mortality factor by determining if an unusually large monthly number of stranded sea turtles ( $>10$ yr mean number of stranded turtles for that month plus 2 standard deviations) ever coincided with red tide and if the brevetoxin concentrations in samples taken from any of those stranded turtles exceeded baseline concentrations (i.e. exceeded the maximum concentration in the corresponding no red tide group). This evaluation was conducted for 19962013 because 1996 was the first year that $10 \mathrm{yr}$ monthly mean numbers of stranded turtles could be calculated.

We estimated the number of stranded sea turtles by species that could be attributed to red tide for 19962013 by first determining the total number of strandings that were found during a red tide in a zone where we identified red tide as a sea turtle mortality factor. To determine the fraction of those strandings attributable to red tide, we then multiplied these totals by the overall percentage of sampled turtles by species found in 1 of these zones during a red tide that had a brevetoxin concentration above the baseline. Finally, we estimated the range of overall sea turtle mortality that could be attributed to red tide by multiplying the number of stranded sea turtles that we attributed to red tide by 5 to estimate the minimum mortality and by 10 to estimate the maximum mortality (assuming stranding probabilities of 10$20 \%$; see Epperly et al. 1996 and Hart et al. 2006).

\section{RESULTS}

\subsection{Strandings, red tides, and regression models}

The number of stranded sea turtles by species and zone, and the number of months of red tide by zone 
in Florida during 1986-2013 are given in Table 2. Unusually large monthly numbers of stranded sea turtles were found coincident with red tide in 10 of the 15 zones (Zones 1, 3-9, 28, and 29). Of the months of red tide combined for these 10 zones during 19962013 ( $N=261$ ), unusually large numbers of stranded sea turtles were found coincident with red tide during $32 \%(\mathrm{~N}=83)$ of those months. About $94 \%$ of these stranded turtles were either dead when found or died soon thereafter. The rest were found alive and then rehabilitated and released. Overall, these stranding numbers exceeded the 10 yr monthly means by a total of 1009 (589 loggerheads, 234 Kemp's ridleys, 175 green turtles, and 11 hawksbills). Stranded leatherbacks were never found in unusually large numbers during a red tide. The stranded loggerheads and Kemp's ridleys found during these times were primarily adults and large immature turtles (mean \pm SD curved carapace length [CCL]: loggerhead $=88.3 \pm 12.9 \mathrm{~cm}$, Kemp's ridley $=43.2 \pm$ $11.5 \mathrm{~cm}$ ). The stranded green turtles and hawksbills were primarily small immature turtles (green turtle $=$ $40.9 \pm 13.5 \mathrm{~cm}$, hawksbill $=40.7 \pm 17.3 \mathrm{~cm}$ ). For all species, the CCLs of stranded sea turtles found in unusually large numbers during a red tide were not different from those of stranded turtles found in the same areas when there was no red tide (Wilcoxon rank sum tests, $p \geq 0.05$ ). Groups of stranded sea tur- tles found in unusually large numbers during a red tide typically had a lower percentage occurrence of external anomalies that indicated another possible cause of death (other than brevetoxicosis) than did similar groups found when there was no red tide (Fig. 2).

The Bayesian Poisson regressions predicted that an ongoing red tide (ORT), a red tide that dissipated during the previous month (LRT), and at least 2 consecutive months of red tide (CRT) would all be associated with significant increases in the numbers of stranded loggerheads and Kemp's ridleys during some months but that only CRT would be associated with significant increases in the number of stranded green turtles during some months (Fig. 3). The effect of LCT, all random effect standard deviations, and the temporal random effect correlation parameters are provided in Table 3.

\subsection{Necropsies and brevetoxin}

Necropsies that included sampling for determination of brevetoxin concentration were conducted on 304 sea turtles (119 Kemp's ridleys, 110 loggerheads, 74 green turtles, and 1 hawksbill). Fauquier et al. (2013a) previously reported the results of some of these necropsies and the findings of the remainder

Table 2. Numbers of months of Karenia brevis red tide and the total number of dead or debilitated (i.e. stranded) sea turtles documented in each of 15 zones in Florida (anticlockwise, west to [north] east; see Fig. 1) during 1986-2013 (excluding strandings of olive ridleys, $\mathrm{N}=4$, and those not identified to species, $\mathrm{N}=1045$ ). We defined a red tide as a $K$. brevis bloom with a concentration of $\geq 10^{5}$ cells $1^{-1}$. The subset of stranded turtles found during a red tide is given in parentheses

\begin{tabular}{|c|c|c|c|c|c|c|c|c|}
\hline \multirow{2}{*}{ Zone } & \multirow{2}{*}{$\begin{array}{l}\text { Number of } \\
\text { months of } \\
\text { red tide }\end{array}$} & \multirow[b]{2}{*}{ Loggerheads } & \multirow{2}{*}{$\begin{array}{l}\text { Green } \\
\text { turtles }\end{array}$} & \multicolumn{2}{|c|}{ Number of stranded sea turtles } & \multirow[b]{2}{*}{$\begin{array}{l}\text { Leather- } \\
\text { backs }\end{array}$} & \multirow[b]{2}{*}{ Total } & \multirow{2}{*}{$\begin{array}{c}\text { Found } \\
\text { during red } \\
\text { tide }(\%)\end{array}$} \\
\hline & & & & $\begin{array}{l}\text { Kemp's } \\
\text { ridleys }\end{array}$ & $\begin{array}{l}\text { Hawks- } \\
\text { bills }\end{array}$ & & & \\
\hline 10 & 6 & $173(10)$ & $45(0)$ & $115(2)$ & $0(0)$ & $21(1)$ & 354 (13) & 3.7 \\
\hline 9 & 12 & $340(25)$ & $59(1)$ & $137(2)$ & $1(0)$ & $36(0)$ & $573(28)$ & 4.9 \\
\hline 8 & 24 & $563(46)$ & $144(7)$ & $302(47)$ & $4(0)$ & $12(0)$ & $1025(100)$ & 9.8 \\
\hline 7 & 11 & $184(18)$ & $54(1)$ & $128(10)$ & $6(0)$ & $4(0)$ & $376(29)$ & 7.7 \\
\hline 6 & 15 & $169(22)$ & $393(12)$ & $108(10)$ & $20(0)$ & $10(0)$ & $700(44)$ & 6.3 \\
\hline 5 & 93 & $1787(645)$ & 733 (223) & $519(244)$ & $60(22)$ & $10(4)$ & 3109 (1138) & 36.6 \\
\hline 4 & 100 & $1685(533)$ & 340 (111) & $463(215)$ & 23 (10) & $8(4)$ & 2519 (873) & 34.7 \\
\hline 3 & 37 & $230(42)$ & $45(3)$ & 81 (49) & $2(0)$ & $0(0)$ & $358(94)$ & 26.3 \\
\hline 1 & 18 & 1416 (143) & 1403 (106) & 34 (1) & $158(7)$ & $33(7)$ & $3044(264)$ & 8.7 \\
\hline 25 & 1 & $514(2)$ & $617(1)$ & $11(0)$ & $93(0)$ & $13(0)$ & $1248(3)$ & 0.2 \\
\hline 26 & 0 & $1165(0)$ & $1699(0)$ & $26(0)$ & $165(0)$ & $71(0)$ & $3126(0)$ & 0.0 \\
\hline 27 & 4 & 2243 (12) & 2797 (19) & $35(0)$ & $49(0)$ & $56(1)$ & $5180(32)$ & 0.6 \\
\hline 28 & 7 & 3255 (68) & $1313(76)$ & $112(4)$ & $19(0)$ & $54(2)$ & $4753(150)$ & 3.2 \\
\hline 29 & 6 & 2656 (59) & 871 (15) & 201 (3) & $21(0)$ & $167(1)$ & $3916(78)$ & 2.0 \\
\hline 30 & 4 & $2256(45)$ & 339 (3) & $272(5)$ & $3(0)$ & $115(0)$ & 2985 (53) & 1.8 \\
\hline All & 338 & $18636(1670)$ & 10852 (578) & 2544 (592) & 624 (39) & $610(20)$ & 33266 (2899) & 8.7 \\
\hline \multicolumn{2}{|c|}{$\begin{array}{l}\text { Found during } \\
\text { red tide }(\%)\end{array}$} & 9.0 & 5.3 & 23.3 & 6.3 & 3.3 & 8.7 & \\
\hline
\end{tabular}




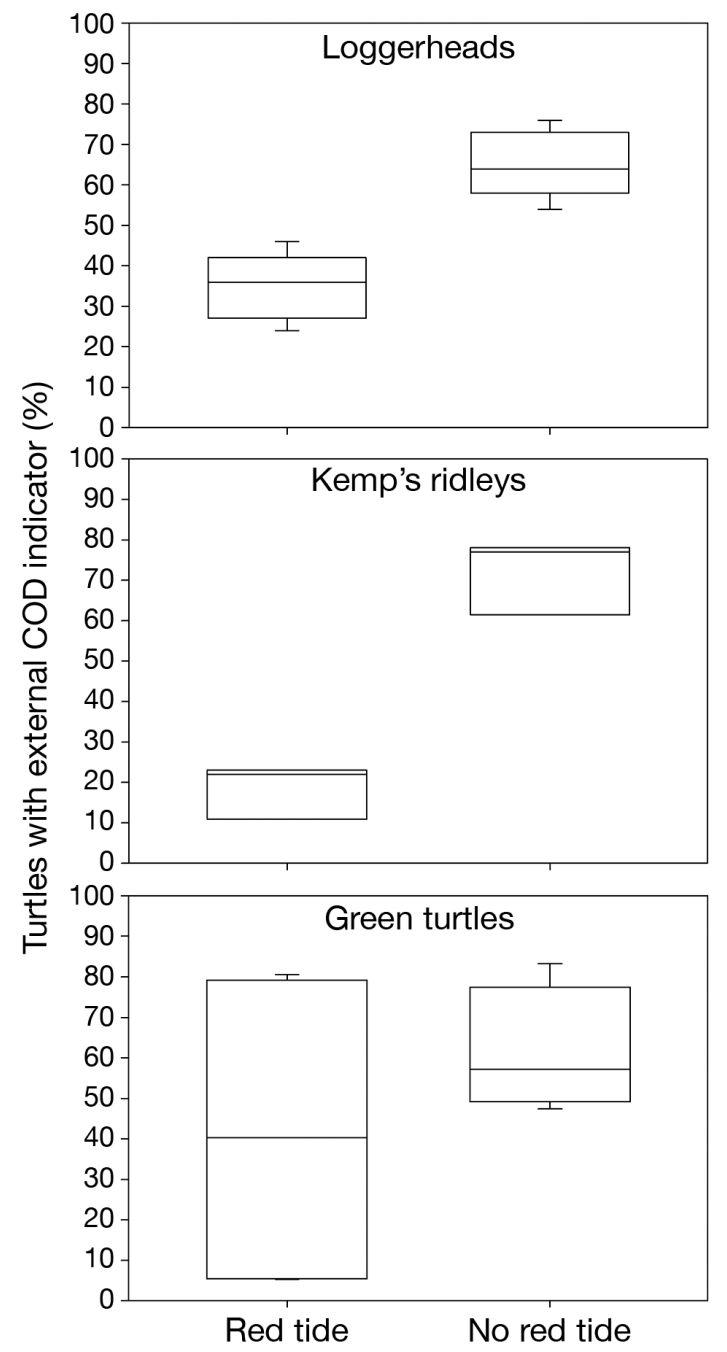

Fig. 2. Percentages of dead-stranded sea turtles with external evidence of a possible cause of death (COD) for groups found in unusually large monthly numbers (>10 yr monthly mean $+2 \mathrm{SD}$ ) during a red tide (Karenia brevis bloom with a concentration of $\geq 10^{5}$ cells $\mathrm{l}^{-1}$ ) and for paired groups found in the same zone and during the same months but when there was no red tide (i.e. the latter were found in different years). Five paired groups of stranded loggerheads, 3 paired groups of stranded Kemp's ridleys, and 4 paired groups of stranded green turtles were used. Externally apparent possible CODs included major injury (e.g. vessel-strike injury or shark-bite injury), entanglement, and indications of disease (e.g. tumors, lesions, or diminished nutritional condition). Paired $t$-tests showed a difference between the 2 categories for loggerheads and Kemp's ridleys $(p=0.015$ and $p<0.001$, respectively) but not for green turtles ( $p \geq 0.05)$. Bar: median; box: interquartile range; whiskers: minimum and maximum

conducted for this study were consistent with those. A dead-stranded sea turtle with suspected brevetoxicosis was typically an animal in fair to good nutritional condition found during a red tide and without gross or histological evidence of primary systemic disease or major injury. Blood or fecal samples (or both) were collected from another 50 live-stranded sea turtles (26 loggerheads, 22 green turtles, and 2 Kemp's ridleys) that were eventually rehabilitated and released.

Brevetoxin concentrations in samples by species (except for the hawksbill and the 1 Kemp's ridley specified below) are summarized in Tables 4-6. Fauquier et al. (2013a) previously reported the results of brevetoxin testing for $28 \%$ of these turtles $(\mathrm{N}=99)$ but they are incorporated here to provide a larger context. The hawksbill was found in Zone 5 during a red tide. It was lethargic with poorly coordinated movements and died shortly after discovery. A necropsy revealed no significant findings. Brevetoxin concentrations in samples from this turtle were as follows: liver, $234 \mathrm{ng} \mathrm{g}^{-1}$; kidney, $85 \mathrm{ng} \mathrm{g}^{-1}$; lung, $47 \mathrm{ng}$ $\mathrm{g}^{-1}$; and contents of the upper gastrointestinal tract, $471 \mathrm{ng} \mathrm{g}^{-1}$. The $1 \mathrm{Kemp}$ 's ridley excluded from Table 5 was found in Zone 1, where red tide had not been documented for more than a year. However, it was found only $15 \mathrm{~km}$ south of Zone 3, where red tide was present at that time. The brevetoxin concentration in samples taken from this turtle were well above those in all other samples taken from turtles found when there was not a red tide or a recent red tide (liver, $1777 \mathrm{ng} \mathrm{g}^{-1}$; contents of the upper gastrointestinal tract, $6333 \mathrm{ng} \mathrm{g}^{-1}$ ).

\subsection{Strandings and mortality attributable to red tide}

Of the 10 zones where unusually large numbers of stranded sea turtles were found coincident with red tides, brevetoxin concentrations above the baseline were documented in samples from stranded turtles associated with red tide in every zone except for Zone 1. Samples taken from 17 stranded loggerheads found during periods of red tide in Zone 1 during 2001, 2003, 2005, and 2006 all tested either negative for brevetoxin or had a concentration within the range of the baseline. In the remaining 9 zones (Zones 3-9, 28, and 29, where we identified red tide as a likely sea turtle mortality factor), a total of 2273 stranded turtles were found coincident with a red tide during 1996-2013 (1298 loggerheads, 505 Kemp's ridleys, 431 green turtles, 32 hawksbills, and 11 leatherbacks). Of these strandings, 189 were sampled to determine brevetoxin concentration (51 loggerheads, $83 \mathrm{Kemp}$ 's ridleys, and 55 green turtles). The percentages of these turtles having a sample with a brevetoxin concentration above the baseline 

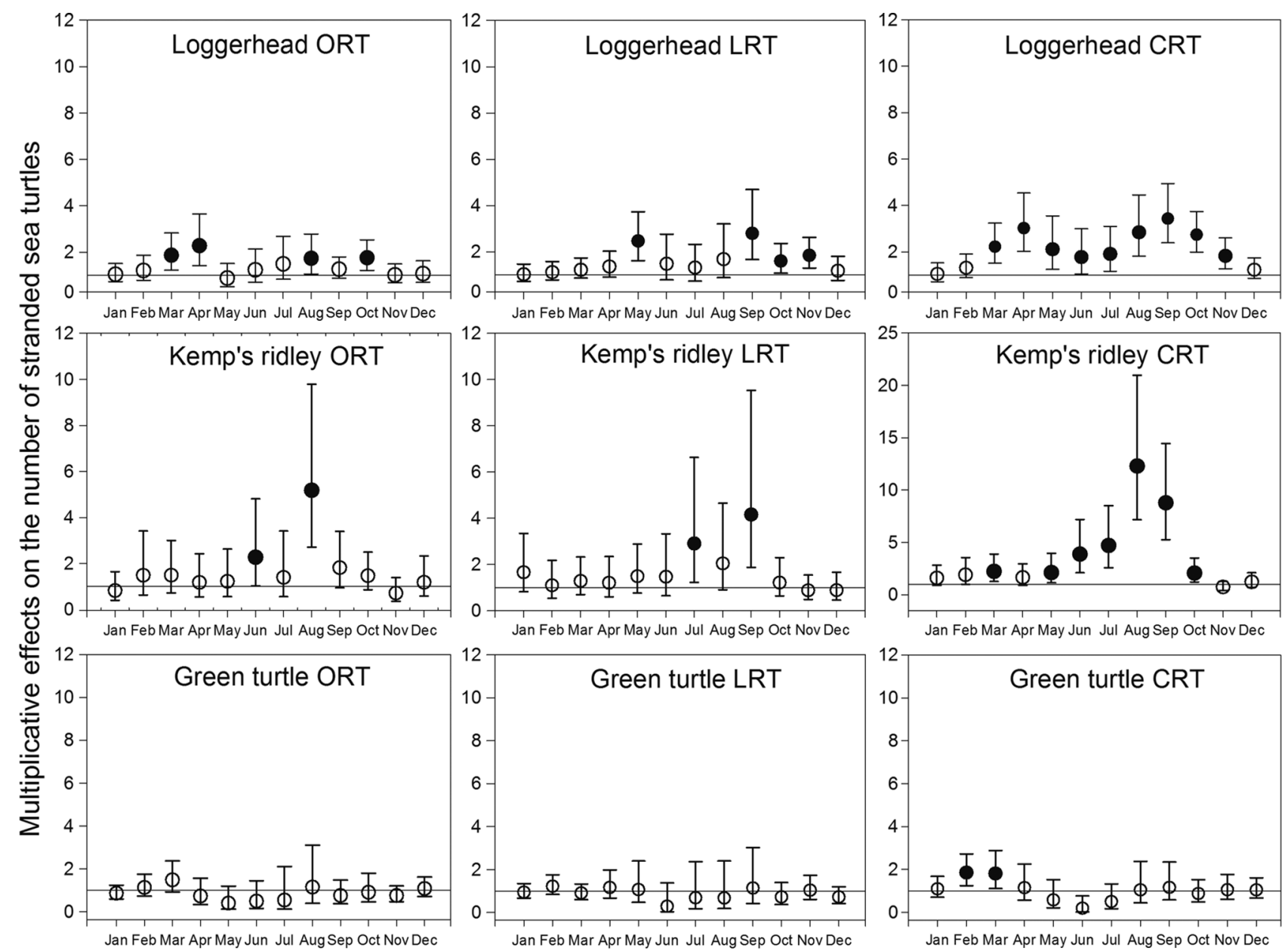

Fig. 3. Predicted multiplicative effects of red tide on the numbers of dead or debilitated (i.e. stranded) loggerheads, Kemp's ridleys, and green turtles by month according to Bayesian Poisson regression models. ORT: ongoing red tide (whether red tide was present in the same zone and during the same month as stranded turtles); LRT: lag red tide (whether red tide was present in the same zone as stranded turtles but during the previous month and not during the same month); CRT: consecutive red tide (whether red tide was present in the same zone as stranded turtles during both the previous month and the same month). A

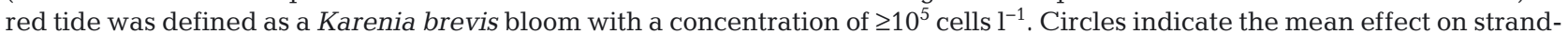
ing numbers and error bars represent the upper and lower $95 \%$ credible intervals. Significant increases are denoted by the solid circles (credible interval does not overlap 1, which is shown as a horizontal line on the graph)

were $73.5 \%$ for Kemp's ridleys, $72.5 \%$ for loggerheads, and $32.4 \%$ for green turtles. The annual number of stranded sea turtles by species attributed to red tide, the percentage of strandings statewide these represented, and the estimated overall mortality from red tide are shown in Table 7 .

\section{DISCUSSION}

\subsection{Red tide as a sea turtle mortality factor and species-specific effects}

Stranded sea turtles found during a Karenia brevis red tide were regularly investigated to identify a pos- sible cause of death. Even though brevetoxicosis was never the likely cause of every stranding during these periods, it appeared to be a predominant cause. Necropsies did not reveal any alternative mortality factor that might regularly account for unusually large numbers of strandings found coincident with red tide. Live strandings found during these periods often presented with clinical signs of brevetoxicosis, and relatively few of the dead strandings had an external anomaly that indicated another possible cause of death. Additionally, the brevetoxin concentrations in samples from these strandings were up to 2 or 3 orders of magnitude greater than the baseline and were often equal to or greater than the concentrations found in tissue samples (e.g. liver, kidney, 
Table 3. Parameter estimates from Bayesian Poisson regressions relating numbers of dead or debilitated (i.e. stranded) sea turtles by species in Florida during 1986-2013 to predictor variables. The parameters shown here include LCT (lag count, i.e. the number of stranded turtles found in the same zone during the previous month), the standard deviation (SD) of the random effect of zone, the temporal correlation of counts estimated from the autoregressive random effect, and the zone-specific (see Fig. 1) temporal SD from the occasion-specific, autoregressive random effect. LCI and UCI are the lower and upper $95 \%$ credible intervals

\begin{tabular}{|c|c|c|c|c|c|c|c|c|c|c|}
\hline \multirow{2}{*}{\multicolumn{2}{|c|}{ Parameter }} & \multicolumn{3}{|c|}{ Loggerhead } & \multicolumn{3}{|c|}{ Green turtle } & \multicolumn{3}{|c|}{ Kemp's ridley } \\
\hline & & Mean & LCI & UCI & Mean & LCI & UCI & Mean & LCI & UCI \\
\hline \multicolumn{2}{|l|}{ LCT } & 0.992 & 0.987 & 0.998 & 0.982 & 0.975 & 0.989 & 0.987 & 0.963 & 1.011 \\
\hline \multicolumn{2}{|c|}{ SD zone random effect } & 1.891 & 0.810 & 4.250 & 3.787 & 1.574 & 8.659 & 1.536 & 0.566 & 3.779 \\
\hline \multicolumn{2}{|c|}{ Temporal correlation } & 0.698 & 0.655 & 0.740 & 0.894 & 0.865 & 0.917 & 0.858 & 0.795 & 0.918 \\
\hline \multirow{15}{*}{$\begin{array}{l}\text { SD temporal } \\
\text { random effect }\end{array}$} & Zone 1 & 0.835 & 0.722 & 0.960 & 0.759 & 0.595 & 0.948 & 0.671 & 0.174 & 1.390 \\
\hline & Zone 3 & 0.738 & 0.490 & 1.016 & 1.179 & 0.757 & 1.789 & 1.095 & 0.807 & 1.454 \\
\hline & Zone 4 & 0.607 & 0.470 & 0.755 & 0.842 & 0.619 & 1.110 & 0.913 & 0.074 & 2.000 \\
\hline & Zone 5 & 0.552 & 0.447 & 0.662 & 0.785 & 0.612 & 0.988 & 0.885 & 0.144 & 1.736 \\
\hline & Zone 6 & 0.549 & 0.461 & 0.641 & 0.755 & 0.617 & 0.914 & 0.385 & 0.060 & 0.915 \\
\hline & Zone 7 & 0.648 & 0.562 & 0.745 & 1.140 & 0.956 & 1.356 & 1.285 & 0.917 & 1.728 \\
\hline & Zone 8 & 0.827 & 0.722 & 0.943 & 1.353 & 1.121 & 1.626 & 1.588 & 1.153 & 2.188 \\
\hline & Zone 9 & 0.903 & 0.675 & 1.176 & 0.671 & 0.247 & 1.213 & 2.177 & 1.505 & 3.129 \\
\hline & Zone 10 & 1.088 & 0.949 & 1.242 & 1.092 & 0.838 & 1.389 & 1.503 & 1.115 & 2.024 \\
\hline & Zone 25 & 0.740 & 0.633 & 0.854 & 1.385 & 1.082 & 1.757 & 1.323 & 1.018 & 1.733 \\
\hline & Zone 26 & 0.725 & 0.620 & 0.845 & 1.703 & 1.358 & 2.093 & 0.755 & 0.564 & 0.986 \\
\hline & Zone 27 & 0.811 & 0.581 & 1.064 & 1.311 & 1.012 & 1.689 & 0.868 & 0.560 & 1.253 \\
\hline & Zone 28 & 0.838 & 0.601 & 1.109 & 1.202 & 0.751 & 1.737 & 1.130 & 0.770 & 1.575 \\
\hline & Zone 29 & 0.759 & 0.585 & 0.964 & 1.706 & 1.236 & 2.298 & 1.166 & 0.864 & 1.554 \\
\hline & Zone 30 & 0.793 & 0.582 & 1.023 & 1.718 & 1.198 & 2.357 & 1.412 & 1.033 & 1.886 \\
\hline
\end{tabular}

and lung) and in gut contents (e.g. stomach contents and feces) of other higher vertebrates suspected of having died from brevetoxicosis (manatees and dolphins: Flewelling et al. 2005, Twiner et al. 2012; canids: Castle et al. 2013; birds: Fauquier et al. 2013b).

The Bayesian Poisson regression models predicted that red tides would be associated with greater and more frequent increases in the numbers of stranded loggerheads and Kemp's ridleys than in the number of stranded green turtles. This was consistent with other results from the present study. For example, a higher percentage of stranded loggerheads and Kemp's ridleys were found during a red tide than stranded green turtles $(9.0$ and $23.3 \%$ vs. 5.3\%, respectively). Also, relatively few of the stranded loggerheads and Kemp's ridleys found during a red tide had an external anomaly that indicated another possible cause of death. This was sometimes true for stranded green turtles but not as consistently. Brevetoxin concentrations in samples taken from stranded loggerheads and Kemp's ridleys found during a red tide were significantly higher than in those taken from strandings found when there had not been a recent red tide. This was not the case for stranded green turtles. Brevetoxin concentrations in samples taken from almost three-quarters of the stranded log- gerheads and Kemp's ridleys found during a red tide had a brevetoxin concentration that exceeded the range of the baseline, but this was only true for about a third of the stranded green turtles.

Overall, green turtles might tend to be exposed to less brevetoxin than loggerheads or Kemp's ridleys because of their diet or their local distribution (or both). Along the southern Gulf coast of Florida, where most of the red tides occurred, green turtles feed primarily on seagrasses (A. M. Foley pers. obs.) and Kemp's ridleys and loggerheads feed primarily on benthic invertebrates (Dodd 1988, Witzell \& Schmid 2005). These diet items can vary considerably in their accumulation of brevetoxin (see Flewelling et al. 2005, Bricelj et al. 2012), and this could account for differences in exposure to brevetoxin among these sea turtle species. Alternatively (or additionally), there may have been differences in local distributions that led to loggerheads and Kemp's ridleys more frequently overlapping with red tide. At a study site along the Gulf coast of Florida, Schmid (1998) documented spatial separation between the herbivorous green turtles and the carnivorous loggerheads and Kemp's ridleys based on apparent differences in foraging habitat preferences. In southwest Florida, green turtles may tend to prefer coastal inland waters, where most of the seagrasses 


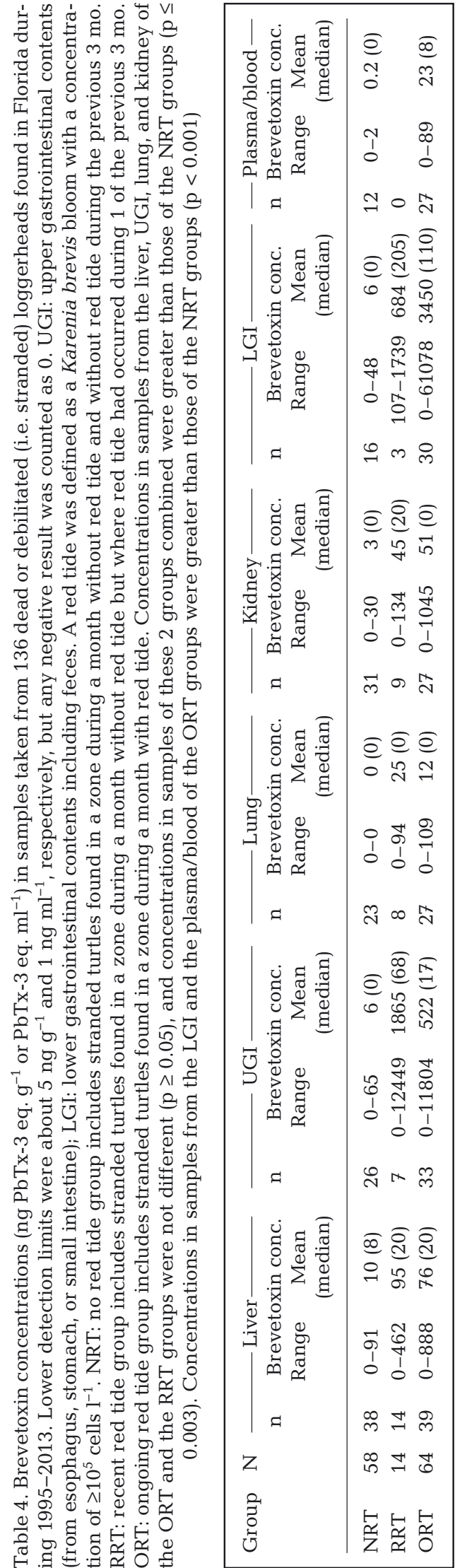

웡

运

ㅋశ శ్ర

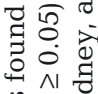

슬. 의

훔

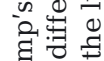

항

ब。

(5)

फ้

访.

वै

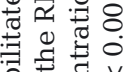

व

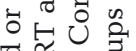

娄

क्ष

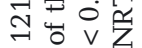

氙 용

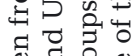

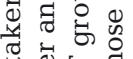

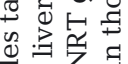

政:

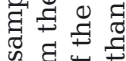

a

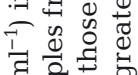

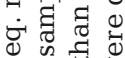

要, 四

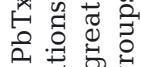

o 0

bo

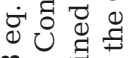

\%

응 영

․ㅗ

ㅁํㅁำ

究

멍

¿ 형

诸

ㅁ

ติ

的搳

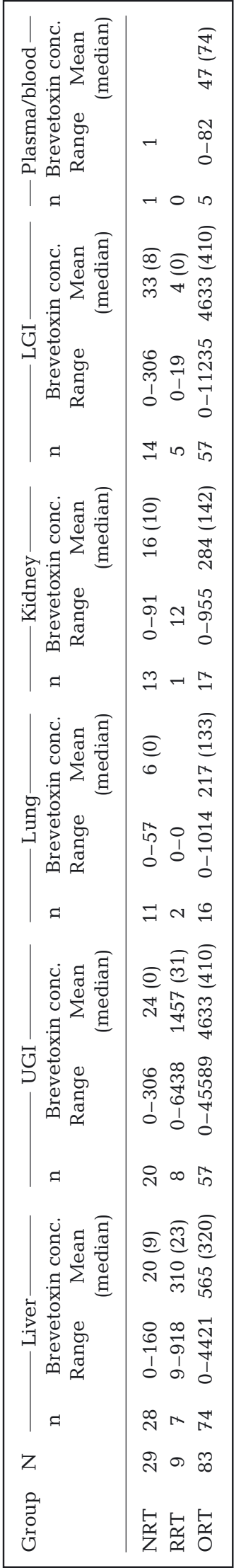

实

윰

일 숭

요

氖

过:

䒿

هీ

s)

票要言

क⿺⿻一⿰冫⿰亅⿱丿丶丶⿱⿰㇒一乂

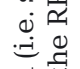

过

훙

to

형

눙

몽 뭉

弍

궁

密:

密

घ 동 잉

䒠跑

宕 영

A.

응

의

ष்

U

숭

马्व.

녹.

送

ष्ठ

范

政

这

至

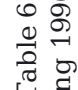

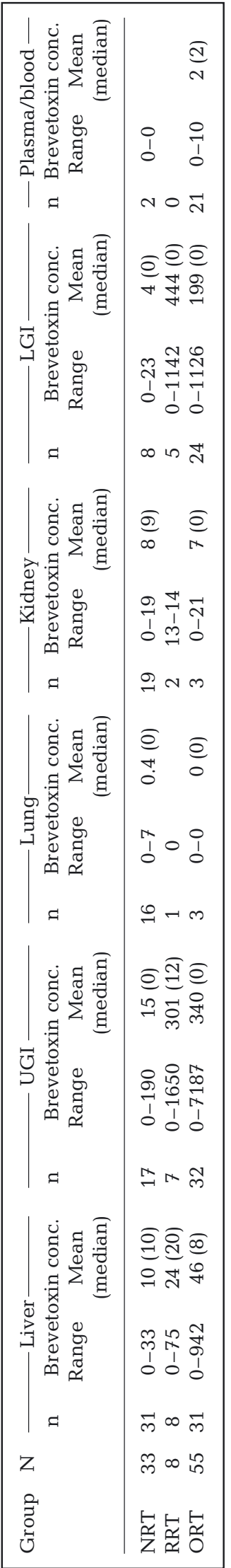


occur (Dawes et al. 2004). Kemp's ridleys and loggerheads occur in coastal inland waters and in shelf waters along the Gulf coast of Florida (Schmid \& Witzell 2006, Hardy et al. 2014, Perrault et al. 2014) but could have a stronger preference for shelf waters than green turtles do. Because of patterns of red tide bloom initiation and transport, and the salinity preferences of $K$. brevis, blooms are more frequent in shelf waters than in coastal inland waters (Steidinger \& Ingle 1972, Tester \& Steidinger 1997, Steidinger 2009). Furthermore, the Bayesian regression model predicted that significant increases in the numbers of stranded green turtles would be associated with red tide only during the late winter and early spring. This was also the time of year when manatees (also herbivorous) living in the coastal inland waters along the southern Gulf coast of Florida experienced periodic large-scale die-offs attributable to red tide (Landsberg et al. 2009). For loggerheads and Kemp's ridleys, the Bayesian regression models predicted that some significant increases in the numbers of stranded turtles would be associated with red tide during the late winter and early spring but that the greatest effects on the stranding numbers for these species would occur during the late summer and fall, which is when red tide blooms are most likely found in shelf waters (Tester \& Steidinger 1997).

\subsection{Distribution of mortality and delayed mortality}

This study investigated sea turtle mortality associated with $K$. brevis red tides over a large spatiotemporal scale (coastal Florida over a 28 yr period) using data that were grouped by zone and month. Mortality was represented by data on sea turtles that were found dead or debilitated (i.e. stranded). Because carcasses or debilitated turtles may drift tens of kilometers and for periods of up to a week or so before being discovered (see Nero et al. 2013), these data only approximated the location and timing of that mortality or debilitation. Some of the stranded turtles may have been found in a different zone than where the mortality or debilitation occurred or during a different month than when the mortality or debilitation occurred. The presence and extent of a $K$. brevis red tide $\left(\geq 10^{5}\right.$ cells $\left.\mathrm{l}^{-1}\right)$ were generally represented by opportunistic water sampling over large areas. When we determined that a red tide was present in a zone during a certain month, it may not have been present in all areas of that zone or in that zone during the entire month. It was also possible that a red tide was present in some zones during some months without being detected by water sampling. Consequently, some associations between sea turtle mortality and red tides could have been obscured by the limitations of these data.

On the scale of the zones used in the present study, the results of brevetoxin testing appeared to represent the expected spatiotemporal aspects of brevetoxin exposure related to $K$. brevis red tides. Brevetoxin concentrations in samples taken from stranded sea turtles found in zones with a red tide were consistently higher and spiked up to 2 or 3 orders of magnitude greater than concentrations in samples taken from stranded turtles found in a zone without a recent red tide. The only exception was relatively high brevetoxin concentrations in samples from 1 stranded Kemp's ridley that was found in a zone without a recent red tide. This carcass likely originated in the adjacent zone (the border of which was only $15 \mathrm{~km}$ from the stranding location) where a red tide was ongoing.

Because high concentrations of brevetoxin may persist in diet items of sea turtles for a few months after a red tide dissipates (in benthic invertebrates and seagrasses; Dickey et al. 1999 and Flewelling et al. 2005, respectively), some delayed mortality related to red tide would not have been unexpected. The Bayesian Poisson regression models predicted that significantly elevated numbers of stranded loggerheads and Kemp's ridleys could continue for 1 mo after a red tide dissipated, and brevetoxin concentrations in samples from strandings of these species found 1-3 mo after a red tide were as high as those from strandings found during a red tide. However, it was possible in these cases that a red tide continued to occur in some portion of a zone for 1 or 2 mo longer than was detected by water sampling. Consequently, some of the stranded turtles categorized as being found shortly after a red tide could have been found during a red tide. In either case, the numbers of stranded loggerheads and Kemp's ridleys that were attributed to red tide in the present study (and the total mortality estimated due to red tide) should be considered a minimum because none of the stranded sea turtles that were found 1-3 mo after a red tide were included in these estimates.

Red tides were almost always located along the Gulf coast of Florida and most of the months of red tide by zone $(68.0 \%)$ and most of the stranded sea turtles documented during a red tide $(72.6 \%)$ were in Zones 3, 4, or 5. One quarter to a little over a third of the stranded sea turtles documented in one of these zones were found during a red tide. Only $6.5 \%$ of the months of red tide by zone were located along the 
Table 7. Number of dead or debilitated (i.e. stranded) sea turtles by species, attributable to Karenia brevis red tide (red tide attributable [RTA] strandings), the percentage of strandings statewide these represented, and the estimated overall mortality from red tide in Florida each year during 1996-2013. RTA strandings were those found during a red tide in Zones 3-9, 28, or 29, multiplied by the percentage of sampled turtles found in 1 of those zones during a red tide that had a brevetoxin concentration above the baseline $(72.5 \%$ for loggerheads, $73.5 \%$ for Kemp's ridleys, and $32.4 \%$ for green turtles). Mortality was estimated using stranding probabilities of $10-20 \%$. A red tide was defined as a $K$. brevis bloom with a concentration of $\geq 10^{5}$ cells $1^{-1}$

\begin{tabular}{|c|c|c|c|c|c|c|c|c|c|}
\hline Year & $\begin{array}{c}\text { RTA } \\
\text { strandings }\end{array}$ & $\begin{array}{c}\text { Loggerheads } \\
\text { Statewide } \\
\%\end{array}$ & $\begin{array}{l}\text { Total } \\
\text { estimated } \\
\text { mortality }\end{array}$ & $\begin{array}{c}\text { RTA } \\
\text { strandings }\end{array}$ & $\begin{array}{c}\text { Kemp's ridleys } \\
\text { Statewide } \\
\%\end{array}$ & $\begin{array}{c}\text { Total } \\
\text { estimated } \\
\text { mortality }\end{array}$ & $\begin{array}{c}\text { RTA } \\
\text { strandings }\end{array}$ & $\begin{array}{l}\text { Green turtle } \\
\text { Statewide } \\
\text { s } \%\end{array}$ & $\begin{array}{l}\text { Total } \\
\text { estimated } \\
\text { mortality }\end{array}$ \\
\hline 1996 & 56 & 9.0 & $280-560$ & 33 & 35.5 & $165-330$ & 22 & 5.0 & $110-220$ \\
\hline 1997 & 7 & 1.3 & $35-70$ & 2 & 2.9 & $10-20$ & 2 & 0.7 & $10-20$ \\
\hline 1998 & 7 & 1.3 & $35-70$ & 5 & 6.6 & $25-50$ & 0 & 0.0 & 0 \\
\hline 1999 & 30 & 6.0 & $150-300$ & 19 & 19.8 & $95-190$ & 3 & 1.2 & $15-30$ \\
\hline 2000 & 34 & 5.1 & $170-340$ & 21 & 18.8 & $105-210$ & 2 & 0.6 & $10-20$ \\
\hline 2001 & 28 & 4.0 & $140-280$ & 14 & 11.6 & $70-140$ & 2 & 0.5 & $10-20$ \\
\hline 2002 & 57 & 8.6 & $285-570$ & 15 & 14.0 & $75-150$ & 7 & 1.9 & $35-70$ \\
\hline 2003 & 159 & 15.0 & $795-1590$ & 56 & 47.1 & $280-560$ & 10 & 1.8 & $50-100$ \\
\hline 2004 & 8 & 1.1 & $40-80$ & 2 & 3.2 & $10-20$ & 5 & 1.5 & $25-50$ \\
\hline 2005 & 226 & 26.1 & $1130-2260$ & 90 & 55.6 & $450-900$ & 22 & 6.3 & $110-220$ \\
\hline 2006 & 167 & 14.2 & $835-1670$ & 28 & 24.6 & $140-280$ & 10 & 2.7 & $50-100$ \\
\hline 2007 & 103 & 11.3 & 515-1030 & 9 & 12.3 & $45-90$ & 21 & 5.2 & $105-210$ \\
\hline 2008 & 4 & 0.6 & $20-40$ & 1 & 1.3 & $5-10$ & 1 & 0.2 & $5-10$ \\
\hline 2009 & 1 & 0.1 & $5-10$ & 1 & 0.9 & $5-10$ & 0 & 0.0 & 0 \\
\hline 2010 & 9 & 1.2 & $45-90$ & 1 & 0.8 & $5-10$ & 1 & 0.1 & $5-10$ \\
\hline 2011 & 13 & 1.6 & $65-130$ & 11 & 5.6 & $55-110$ & 10 & 1.1 & $50-100$ \\
\hline 2012 & 8 & 1.3 & $40-80$ & 30 & 18.6 & $150-300$ & 11 & 1.8 & $55-110$ \\
\hline 2013 & 23 & 3.0 & $115-230$ & 32 & 14.3 & $160-320$ & 9 & 1.1 & $45-90$ \\
\hline Annual mean & 52 & 7.1 & $260-520$ & 21 & 17.7 & $105-210$ & 8 & 1.6 & $40-80$ \\
\hline Total & 940 & 7.1 & $4700-9400$ & 370 & 17.7 & $1850-3700$ & 138 & 1.6 & $690-1380$ \\
\hline
\end{tabular}

Atlantic coast. Nevertheless, unusually large numbers of stranded loggerheads and green turtles $(\mathrm{n}=$ 34 and 51, respectively) were documented along the Atlantic coast of Florida coincident with a red tide. This occurred in Zones 28 and 29 during OctoberDecember 2007. A mass mortality event of bottlenose dolphins and manatees was also attributed to that red tide (Fire et al. 2015).

\subsection{Overall mortality from red tide and management considerations}

$K$. brevis red tides in Florida were a periodically significant mortality factor of loggerheads, Kemp's ridleys, and green turtles along the Gulf coast of Florida, particularly along the southern part of that coast. A few hawksbill mortalities were also likely related to red tides in this area, but there were no indications from strandings that red tides caused mortality of any leatherbacks. However, strandings of leatherbacks were rare where most of the red tides occurred and may have been a particularly poor representation of mortality. During 1996-2013, red tide likely caused considerable sea turtle mortality over relatively short periods (months to a year), and in 1 year (2005) it probably accounted for about a quarter of all strandings statewide. Over the entire $18 \mathrm{yr}$ period, red tide appeared to account for a substantial portion of stranded loggerheads and Kemp's ridleys (7.1 and $17.7 \%$, respectively), but only a small portion of the stranded green turtles $(1.6 \%)$.

Landsberg et al. (2009) identified a combination of environmental, geographical, and biological conditions apparently necessary for a $K$. brevis red tide to cause substantial manatee mortality in Florida. This was used to explain why this degree of mortality did not always occur when red tide was present. A similar situation is likely required for red tide to cause substantial mortality of sea turtles in Florida. Unusually large numbers of stranded sea turtles were not documented during about two-thirds of the months of red tide by zone. However, we did attribute some sea turtle mortality to red tide even when it was not associated with unusually high stranding numbers because brevetoxin concentrations in samples from stranded turtles found during any red tide were often greater than the baseline. 
Preventing or controlling $K$. brevis red tides is challenging because of the large spatial scale of blooms or bloom initiation areas, the excessive costs and difficult logistics of any treatment applications, and the desire to avoid unintended adverse biological or ecological consequences (Steidinger 2009). Current management of $K$. brevis red tides primarily involves monitoring, regulation, and education to limit the risk of brevetoxin exposure for people (Steidinger 2009). As a part of the recovery efforts for threatened or endangered species such as sea turtles, direct management of $K$. brevis red tides is not a viable option, but quantifying and monitoring mortality from this source allows a more complete accounting of natural mortality factors and their overall effects.

Acknowledgements. We are grateful for the dedicated efforts of the participants in the Florida Sea Turtle Stranding and Salvage Network (FLSTSSN). We thank B. Crowder, M. van Deventer, R. Boughton, and several anonymous reviewers for their comments on the manuscript. This study was funded by the Florida Sea Turtle License Plate and the National Oceanic and Atmospheric Administration (NOAA) of the US Department of Commerce. Funding support from NOAA was provided specifically through a grant in 2005 (Purchase Order number DG133F05SE6776) and generally through a series of grants (including Species Recovery Grants to States) supporting the overall work of the FLST SSN during the study period. The statements and findings are those of the authors and do not necessarily reflect the view of NOAA or the Department of Commerce. This work was conducted under the authorization of an ESA Section 6 agreement between the US Fish and Wildlife Service and the Florida Fish and Wildlife Conservation Commission.

\section{LITERATURE CITED}

Akaike H (1973) Information theory and an extension of the maximum likelihood principle. In: Petran BN, Csaaki F (eds) Second international symposium on information theory. Akademiai Kiado, Budapest, p 267-281

Atwood KE (2008) Brevetoxin body burdens in seabirds of southwest Florida. MSc thesis, University of South Florida, St. Petersburg, FL

Baden DG (1989) Brevetoxins: unique polyether dinoflagellate toxins. FASEB J 3:1807-1817

* Bossart GD, Baden DG, Ewing RY, Roberts B, Wright SD (1998) Brevetoxicosis in manatees (Trichechus manatus latirostris) from the 1996 epizootic: gross, histologic, and immunohistochemical features. Toxicol Pathol 26:276-282

Bricelj VM, Haubois AG, Sengco MR, Pierce RH, Culter JK, Anderson DM (2012) Trophic transfer of brevetoxins to the benthic macrofaunal community during a bloom of the harmful dinoflagellate Karenia brevis in Sarasota Bay, Florida. Harmful Algae 16:27-34

Capper A, Flewelling LJ, Arthur K (2013) Dietary exposure to harmful algal bloom (HAB) toxins in the endangered manatee (Trichechus manatus latirostris) and green sea turtle (Chelonia mydas) in Florida, USA. Harmful Algae 28:1-9
Castle KT, Flewelling LJ, Bryan J II, Kramer A and others (2013) Coyote (Canis latrans) and domestic dog (Canis familiaris) mortality and morbidity due to a Karenia brevis red tide in the Gulf of Mexico. J Wildl Dis 49: 955-964

Clark JA, Hoekstra JM, Boersma PD, Kareiva P (2002) Improving U.S. Endangered Species Act recovery plans: key findings and recommendations of the SCB recovery plan project. Conserv Biol 16:1510-1519

Cocilova CC, Milton SL (2016) Characterization of brevetoxin $(\mathrm{PbTx}-3)$ exposure in neurons of the anoxia-tolerant freshwater turtle (Trachemys scripta). Aquat Toxicol 180:115-122

* Davis CC (1948) Gymnodium brevis sp. nov., a cause of discolored water and animal mortality in the Gulf of Mexico. Bot Gaz 109:358-360

Dawes CJ, Phillips RC, Morrison G (2004) Seagrass communities of the Gulf Coast of Florida: status and ecology. Florida Fish and Wildlife Conservation Commission Fish and Wildlife Research Institute and the Tampa Bay Estuary Program, St. Petersburg, FL

* Dickey R, Jester E, Granade R, Mowdy D and others (1999) Monitoring brevetoxins during a Gymnodinium breve red tide: comparison of sodium channel specific cytotoxicity assay and mouse bioassay for determination of neurotoxic shellfish toxins in shellfish extracts. Nat Toxins 7:157-165

Dodd CK Jr (1988) Synopsis of the biological data on the loggerhead sea turtle Caretta caretta (Linnaeus 1758). US Fish and Wildlife Service Biol Rep 88. USFWS, Washington, DC

Epperly SP, Braun J, Chester AJ, Cross FA, Merriner JV, Tester PA, Churchill JH (1996) Beach strandings as an indicator of at-sea mortality of sea turtles. Bull Mar Sci 59:289-297

Fauquier DA, Flewelling LJ, Maucher J, Manire CA and others (2013a) Brevetoxin in blood, biological fluids, and tissues of sea turtles naturally exposed to Karenia brevis blooms in central west Florida. J Zoo Wildl Med 44: 364-375

Fauquier DA, Flewelling LJ, Maucher JM, Keller M and others (2013b) Brevetoxicosis in sea birds naturally exposed to Karenia brevis blooms along the central west coast of Florida. J Wildl Dis 49:246-260

Fire SE, Fauquier D, Flewelling LJ, Henry M, Naar J, Pierce R, Wells RS (2007) Brevetoxin exposure in bottlenose dolphins (Tursiops truncatus) associated with Karenia brevis blooms in Sarasota Bay, Florida. Mar Biol 152: 827-834

Fire SE, Flewelling LJ, Stolen M, Noke Durden W, de Wit M, Spellman AC, Wang Z (2015) Brevetoxin-associated mass mortality event of bottlenose dolphins and manatees along the east coast of Florida, USA. Mar Ecol Prog Ser 526:241-251

Flewelling LJ (2008) Vectors of brevetoxins to marine mammals. PhD dissertation, University of South Florida, St. Petersburg, FL

FFlewelling LJ, Naar JP, Abbott JP, Baden DG and others (2005) Brevetoxicosis: red tides and marine mammal mortalities. Nature 435:755-756

Foley AM, Schroeder BA, Redlow AE, Fick-Child KJ, Teas WG (2005) Fibropapillomatosis in stranded green turtles (Chelonia mydas) from the eastern United States (1980-98): trends and associations with environmental factors. J Wildl Dis 41:29-41 
Forrester DJ, Gaskin JM, White FH, Thompson NP, Quick JA, Henderson G, Woodard JC (1977) An epizootic of waterfowl associated with a red tide episode in Florida. J Wildl Dis 13:160-167

Gelman A, Hill J (2007) Data analysis using regression and multilevel/hierarchical models. Cambridge University Press, New York, NY

* Gelman A, Rubin DB (1992) Inference from iterative simulation using multiple sequences. Stat Sci 7:457-472

Geraci JR (1989) Clinical investigation of the 1987-88 mass mortality of bottlenose dolphins along the U.S. central and south Atlantic coast. Final report to the National Marine Fisheries Service, US Navy Office of Naval Research and Marine Mammal Commission. Ontario Veterinary College, University of Guelph, Guelph

*Hardy RF, Tucker AD, Foley AM, Schroeder BA, Giove RJ, Meylan AB (2014) Spatiotemporal occurrence of loggerhead turtles (Caretta caretta) on the west Florida shelf and apparent overlap with a commercial fishery. Can J Fish Aquat Sci 71:1924-1933

* Hart KM, Mooreside P, Crowder LB (2006) Interpreting the spatio-temporal patterns of sea turtle strandings: going with the flow. Biol Conserv 129:283-290

Kéry M, Schaub M (2010) Bayesian population analysis using WinBUGS: a hierarchical perspective. Academic Press, Waltham, MA

Kreuder C, Mazet JAK, Bossart GD, Carpenter TE, Holyoak M, Elie MS, Wright SD (2002) Clinicopathologic features of suspected brevetoxicosis in double-crested cormorants (Phalacrocorax auritus) along the Florida Gulf coast. J Zoo Wildl Med 33:8-15

Landsberg JH (2002) The effects of harmful algal blooms on aquatic organisms. Rev Fish Sci 10:113-390

* Landsberg JH, Flewelling LJ, Naar J (2009) Karenia brevis red tides, brevetoxins in the food web, and impacts on natural resources: decadal advancements. Harmful Algae 8:598-607

Kawler JJ, Campbell SP, Guerry AD, Kolozsvary MB, O'Connor RJ, Seward LCN (2002) The scope and treatment of threats in endangered species recovery plans. Ecol Appl 12:663-667

McFarren EF, Tanabe H, Silva FJ, Wilson WB, Campbell JE, Lewis KH (1965) The occurrence of a ciguatera-like poison in oysters, clams, and Gymnodinium breve cultures. Toxicon 3:111-123

Murphy EB, Steidinger KA, Roberts BS, Williams J, Jolley JW (1975) An explanation for the Florida east coast Gymnodinium breve red tide of November 1972. Limnol Oceanogr 20:481-486

Naar J, Bourdelais A, Tomas C, Kubanek J and others (2002) A competitive ELISA to detect brevetoxins from Karenia brevis (formerly Gymnodinium breve) in seawater, shellfish, and mammalian body fluid. Environ Health Perspect 110:179-185

Nero RW, Cook M, Coleman AT, Solangi M, Hardy R (2013) Using an ocean model to predict likely drift tracks of sea turtle carcasses in the north central Gulf of Mexico. Endang Species Res 21:191-203

* O'Shea TJ, Rathbun GB, Bonde RK, Buergelt CD, Odell DK (1991) An epizootic of Florida manatees associated with a dinoflagellate bloom. Mar Mamm Sci 7:165-179

Owens DW, Ruiz GJ (1980) New methods of obtaining blood and cerebrospinal fluid from marine turtles. Herpetologica $36: 17-20$
Perrault JR, Schmid JR, Walsh CJ, Yordy JE, Tucker AD (2014) Brevetoxin exposure, superoxide dismutase activity and plasma protein electrophoretic profiles in wildcaught Kemp's ridley sea turtles (Lepidochelys kempii) in southwest Florida. Harmful Algae 37:194-202

* Perrault JR, Bauman KD, Greenan TM, Blum PC, Henry MS, Walsh CJ (2016) Maternal transfer and sublethal immune system effects of brevetoxin exposure in nesting loggerhead sea turtles (Caretta caretta) from western Florida. Aquat Toxicol 180:131-140

Plummer M (2003) JAGS: a program for analysis of Bayesian graphical models using Gibbs sampling. In: Hornik $\mathrm{K}$, Leisch F, Zeileis A (eds) Proceedings of the 3rd International Workshop on Distributed Statistical Computing (DSC 2003), March 20-22. Technische Universität Wien

Quick JA, Henderson GE (1975) Evidences of new ichthyointoxicative phenomena in Gymnodinium breve red tides. In: LoCicero VR (ed) Proceedings of the First International Conference on Toxic Dinoflagellate Blooms. Science and Technology Foundation, Wakefield, MA, p 413-422

R Development Core Team (2008) R: a language and environment for statistical computing. R Foundation for Statistical Computing, Vienna

Schmid JR (1998) Marine turtle populations on the westcentral coast of Florida: results of tagging studies at the Cedar Keys, Florida, 1986-1995. Fish Bull 96: 589-602

Schmid JR, Witzell WN (2006) Seasonal migrations of immature Kemp's ridley turtles (Lepidochelys kempii Garman) along the west coast of Florida. Gulf Mex Sci 24:28-40

Steidinger KA (2009) Historical perspective on Karenia brevis red tide research in the Gulf of Mexico. Harmful Algae 8:549-561

Steidinger KA, Ingle RM (1972) Observations on the 1971 summer red tide in Tampa Bay. Florida. Environ Lett 3: 271-278

*Tester PA, Steidinger KA (1997) Gymnodinium breve red tide blooms: initiation, transport, and consequences of surface circulation. Limnol Oceanogr 42:1039-1051

* Tester PA, Stumpf RP, Vukovich FM, Fowler PK, Turner JT (1991) An expatriate red tide bloom: transport, distribution, and persistence. Limnol Oceanogr 36:1053-1061

* Twiner MJ, Fire S, Schwacke L, Davidson L and others (2011) Concurrent exposure of bottlenose dolphins (Tursiops truncatus) to multiple algal toxins in Sarasota Bay, Florida, USA. PLOS ONE 6:e17394

* Twiner MJ, Flewelling LJ, Fire SE, Bowen-Stevens SR and others (2012) Comparative analysis of three brevetoxinassociated bottlenose dolphin (Tursiops truncatus) mortality events in the Florida Panhandle region (USA). PLOS ONE $7: \mathrm{e} 42974$

*van Deventer M, Atwood K, Vargo GA, Flewelling LJ, Landsberg JH, Naar JP, Stanek D (2012) Karenia brevis red tides and brevetoxin-contaminated fish: a high risk factor for Florida's scavenging shorebirds? Bot Mar 55: $31-37$

Vargo GA, Heil CA, Fanning KA, Bell S (2008) Nutrient availability in support of Karenia brevis blooms on the central west Florida shelf: What keeps Karenia blooming? Cont Shelf Res 28:73-98

Walsh JJ, Steidinger KA (2001) Saharan dust and Florida red tides: the cyanophyte connection. J Geophys Res 106: $11597-11612$ 
Walsh JJ, Jolliff JK, Darrow BP, Lenes JM and others (2006) Red tides in the Gulf of Mexico: where, when, and why? J Geophys Res 111:C11003

Weisberg RH, Zheng L, Liu Y, Corcoran AA and others (2016) Karenia brevis blooms on the west Florida shelf: a comparative study of the robust 2012 bloom and the nearly null 2013 event. Cont Shelf Res 120:106-121

Whitney PL, Delgado JA, Baden DG (1997) Complex behavior of marine animal tissue extracts in the competitive

Editorial responsibility: Stephen Feist, Weymouth, UK binding assay of brevetoxins with rat brain synaptosomes. Nat Toxins 5:193-200

Witzell WN, Schmid JR (2005) Diet of immature Kemp's ridley turtles (Lepidochelys kempi) from Gullivan Bay, Ten Thousand Islands, southwest Florida. Bull Mar Sci 77 : 191-199

Wolke RE, George A (1981) Sea turtle necropsy manual. Tech Memo NMFS-SEFC-24. NOAA, NMFS Southeast Fisheries Centre, Panama City, FL

Submitted: February 12, 2018; Accepted: October 18, 2018 Proofs received from author(s): December 18, 2018 